\author{
Slawomir Dorocki \\ Uniwersytet Pedagogiczny \\ im. Komisji Edukacji Narodowej \\ w Krakowie
}

\title{
Inwestycje zagraniczne we Francji w dobie globalizacji
}

Ostatnie 50 lat, a w szczególności przełom XX i XXI w., to okres znaczącej intensyfikacji międzynarodowych powiązań ekonomicznych, będących częścią ogólnego procesu globalizacji gospodarki światowej. W wyniku tych procesów nastąpiło m.in. zwiększanie się stopnia otwartości gospodarek państw, co z kolei wpłynęło na wzrost roli inwestycji zagranicznych jako czynnika wzrostu gospodarczego kraju (Majewska, Grala 2002).

Współcześnie inwestycje zagraniczne nie tylko warunkują rozwój poszczególnych państw, lecz także stanowią ważny czynnik rozwoju regionalnego. Na wagę bezpośrednich inwestycji zagranicznych w procesie wzrostu gospodarczego zarówno w ujęciu krajowym, jak i zagranicznym zwrócili uwagę w swych publikacjach m.in.: Kudełko (1996), Chojnicki (1999), Domański (2002), Bojar (2001), Namyślak (2002), Gorzelak (2003), Stryjakiewicz (2004), Sala (2006), Sobala-Gwosdz (2006), Zioło (2006) i Brezdeń (2006).

Bezpośrednie inwestycje zagraniczne (BIZ) stanowią obecnie jedną z najbardziej pożądanych form dopływu zagranicznego kapitału do kraju. Wśród przytaczanych atutów inwestycji znajdują się m.in.: brak zadłużenia zagranicznego, generowanie wzrostu gospodarczego kraju oraz przyczynianie się do spadku bezrobocia. Ponadto inwestycje powodują przepływ technologii, wprowadzają innowacyjne metody zarządzania, otwierają dostęp do nowych rynków oraz wspomagają rozwój infrastruktury produkcyjnej. Potwierdzeniem istotności BIZ może być fakt, że w pozyskiwanie inwestycji zagranicznych zaangażowane są głowy największych państw świata, a sam wybór kraju jako miejsca inwestycji odbierany jest jako sukces całej ekipy rządzącej.

W części pierwszej prezentowanego opracowania dokonano krótkiej charakterystyki inwestycji zagranicznych we Francji na tle innych państw. Następnie przedstawiono regionalne zróżnicowanie tych inwestycji w oparciu o liczbę inwestycji oraz miejsc pracy generowanych przez bezpośrednie inwestycje zagraniczne. Na koniec zanalizowano czynniki wpływające na lokalizacje inwestycji zagranicznych. Należy tu zaznaczyć, że w przypadku badania zależności tych procesów rodzi się pytanie o kierunek oraz relacje, jakie zachodzą pomiędzy badanymi zjawiskami (zależność bądź współwystępowanie). Dokonując porównań, wykorzystano dane odnoszące się do czynników mogących stanowić stymulanty inwestycji. Analizowane czynniki występowały wcześniej niż sama inwestycja, nie można jednakże wykluczyć możliwości, że badane inwestycje trafiają do regionów wcześniej już wypromowanych, zgodnie z modelem kumulatywnej przyczynowości Myrdala (1957). Uwzględniając powyższą możliwość, badane stymulanty byłyby zatem wynikiem inwestycji, a nie ich inicjatorem. Mielibyśmy więc do czynienia z współwystępowaniem, a nie - zależnością badanych procesów.

W analizie wykorzystano dane statystyczne publikowane przez Bank Francji (Banque de France), w tym głównie roczne bilanse i raporty: Bilan sur les investissements étrangers en 
Franc Tableau de bord de l'attractivité de la France oraz Bilan des investissements étrangers créateurs d'emploi en France. Ponadto wykorzystano dane dotyczące wielkości inwestycji, zawarte w zestawieniach OECD i UNCTAD (United Nations Conference on Trade and Development) World investment report.

Na wstępie rozważań nad problemem inwestycji zagranicznych we Francji trzeba wspomnieć o funkcjonującym w tym kraju od lat scentralizowanym systemie administracji państwowej, obejmującym również decyzje inwestycyjne. Głównym organem państwowym jest Francuska Agencja Inwestycji Zagranicznych (AFII - Agence Française pour les Investissements Internationaux) działająca na rzecz pozyskania inwestorów zagranicznych. Ponadto każdy region posiada osobną instytucję promującą daną jednostkę wśród zagranicznych inwestorów.

Wśród działań rządu należy wymienić funkcjonujący od 1982 r. system subwencji dla inwestorów (który w 2008 r. wyniósł 20 mld euro), strefy bezcłowe, wprowadzone w $1992 \mathrm{r}$. zwolnienia od kosztów społecznych oraz powstałe w 1996 r. (a zmodyfikowane w 2008 r.) obszary i strefy działań dla inwestycji szczególnie istotnych dla rozwoju gospodarczego. Inwestorzy w powstałych strefach i sektorach gospodarki mogą uzyskać całkowite zwolnienie od podatku dochodowego oraz od kosztów socjalnych, okresowe zwolnienia z podatku zawodowego, zwolnienia od podatku gruntowego, a nawet zwolnienia od podatku dochodowego od osób fizycznych dla rzemieślników i handlowców. Odrębną kwestią jest wspieranie przez państwo badań i rozwoju oraz pomoc publiczna w zakresie szkoleń zawodowych pracowników, również w odniesieniu do inwestycji zagranicznych. Wszystkie podjęte działania są skierowane z jednej strony na przyciągnięcie inwestorów, a z drugiej - na zrównanie uprawnień inwestorów zagranicznych i krajowych oraz zrównanie ich uprawnień odnośnie prowadzonej działalności gospodarczej.

Powyższe działania rządu oraz uwarunkowania międzynarodowe przyniosły w ostatnich latach pożądane efekty. Francja w 2009 r. zajęła trzecie miejsce na świecie (a pierwsze w Europie) pod względem wielkości napływu BIZ oraz drugie miejsce pod względem ich odpływu (UNCTAD 2010). Również w 2009 r. zajęła drugie miejsce w Europie, jeśli chodzi o liczbę projektów realizowanych dzięki BIZ (Ernst\&Young 2010). Od 2007 r. Francja jest drugim krajem w Europie co do liczby miejsc pracy stworzonych przez BIZ (Ernst\&Young 2010). W 2009 r. miała największy udział w wartości BIZ w sektorze B+R i przemysłu w Europie (pierwsze miejsce w technologiach ekologicznych) (AFII 2010). Francja zajmuje także pierwsze miejsce wśród krajów Europy pod względem liczby miejsc pracy stworzonych przez BIZ w sektorze B+R (AFII 2010). Dodatkowo Paryż jest drugim największym na świecie miastem pod względem lokalizacji siedzib międzynarodowych firm (UNCTAD 2010). Wszystkie te wskaźniki wpłynęły pośrednio na wybór Francji jako obiektu badań. Dodatkowo odnotować należy, że kraj ten osiągnął dobre wyniki przy wysokiej stawce podatku oraz wysokich kosztach pracy.

W badaniach wykorzystano francuską terminologię statystyczną, według której bezpośrednie inwestycje zagraniczne (Investissements directs étrangers - IDE) to inwestycje mające na celu uzyskanie trwałego udziału w podmiotach gospodarczych posiadających siedzibę w innym państwie. Są to inwestycje, które mają znaczący wpływ na zarządzanie przedsiębiorstwem (inwestor nabywa co najmniej 10\% kapitału inwestycji). Inwestycje bezpośrednie obejmują nie tylko wstępną transakcję, ale również wszystkie późniejsze transakcje kapitałowe pomiędzy podmiotami $^{1}$.

\footnotetext{
${ }^{1}$ Institut national de la statistique et des études économiques - Définitions et méthodes, 2010, http://www. insee.fr/fr/methodes/
} 
Rozpoczynając poniższą analizę, należy podkreślić, że Francja pod względem udziału wartości inwestycji zagranicznych od wielu lat znajduje się w ścisłej czołówce światowej. Jak widać na przedstawionym wykresie (ryc. 1), wśród pozostałych państw gromadzących prawie połowę wartości światowych inwestycji zagranicznych tylko ona odnotowała wzrost udziału z 4,5\% w 1980 r. do ponad 6\% w 2006 r. Potwierdza to zamieszczone powyżej informacje o wzroście zainteresowania tym krajem wśród zagranicznych inwestorów. Szczególne wyraźnie proces ten widoczny jest w ostatnich latach, w których Francja odnotowała najmniejsze spadki udziału w wartości inwestycji zarówno w aspekcie napływu, jak i odpływu inwestycji zagranicznych w odniesieniu do innych rozwiniętych krajów świata.

Ryc. 1. Udział Francji w wartości światowych inwestycji zagranicznych w latach 1980-2007 oraz saldo BIZ w latach 2007-2009 na tle wybranych państw
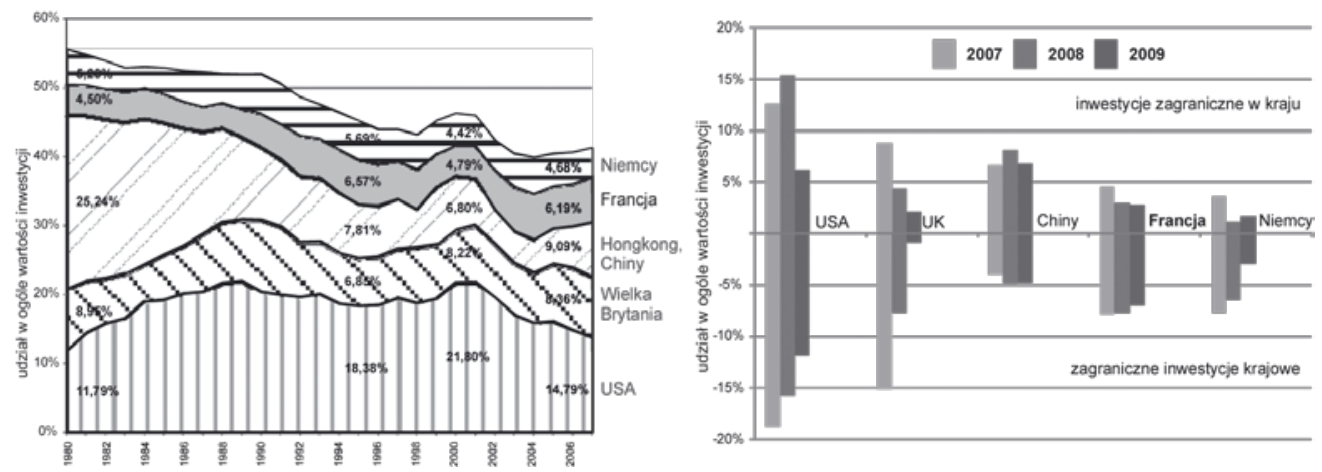

Źródło: opracowanie własne na podstawie danych UNCTAD.

Ryc. 2. Inwestycje zagraniczne w Europie oraz wybranych rozwiniętych krajach świata w stosunku do PKB kraju w 2009 r.

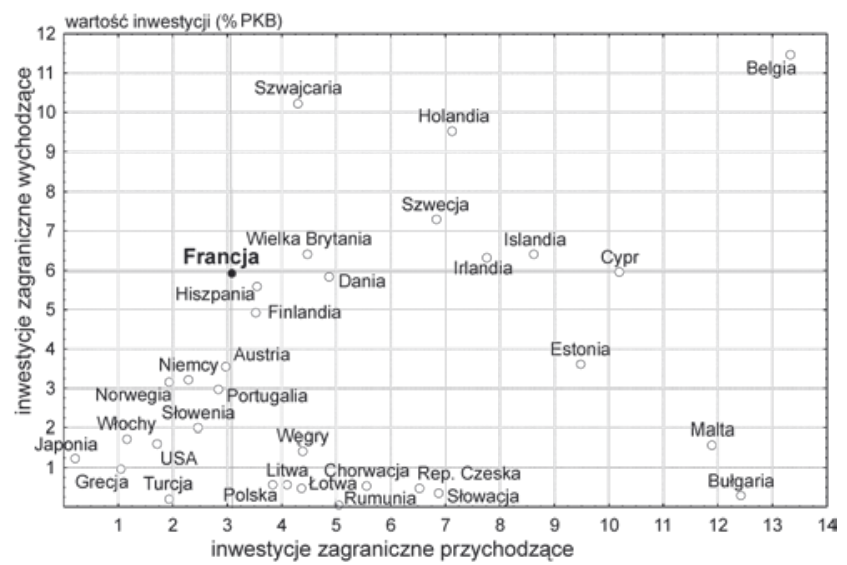

Źródło: opracowanie własne na podstawie danych EUROSTAT.

Przy porównywaniu powyższych zestawień rodzi się wątpliwość, czy zmiany zachodzące w udziale poszczególnych krajów w wielkości inwestycji nie są wynikiem jedynie wzrostu potencjału gospodarczego Francji, przy braku innych stymulantów proinwestycyjnych. Odpowiedź 
na to pytanie można pośrednio odnaleźć w zestawieniu wielkości inwestycji w odniesieniu do wielkości PKB (ryc. 2). Porównując zatem wielkości inwestycji zagranicznych jako udziału wielkości produktu krajowego brutto w 2009 r., widzimy, że wartość inwestycji napływających do Francji (ok. 3\% wielkości PKB) jest prawie dwukrotnie wyższa niż w innych państwach rozwiniętych, np. w Niemczech, we Włoszech czy w Stanach Zjednoczonych. Francja zajmuje również wysoką pozycję wśród krajów europejskich w odniesieniu do własnych inwestycji zagranicznych, które stanowią ok. 6\% wielkości PKB. Powyższe zestawienie potwierdza wysoką pozycję tego kraju w odniesieniu do rynku inwestycyjnego świata oraz świadczy o wysokim stopniu umiędzynarodowienia gospodarki francuskiej.

Francja od lat 90. XX w. utrzymuje stałą tendencję wzrostową, zarówno w odniesieniu do wartości napływu inwestycji zagranicznych do kraju, jak i ich odpływu. W wyniku postępujących procesów globalizacji, przejawiających się m.in. w zjawiskach delokalizacji inwestycji ze względu na koszty produkcji, od końca XX w. zauważalny jest we Francji wzrost ujemnego salda wymiany inwestycyjnej z zagranicą. O procesach delokalizacji świadczy także wysoki udział inwestycji zagranicznych w krajach wschodniej Europy (ryc. 3). Dodatkowo należy zwrócić uwagę na spadek inwestycji we Francji na początku XX w., co mogło mieć swoje konsekwencje we wdrażaniu działań przedakcesyjnych do UE w Europie Środkowej i Wschodniej, oraz mniej wyraźny spadek wywołany kryzysem światowym. Charakterystyczny dla współczesnych inwestycji we Francji wyraźny wzrost wielkości inwestycji na jednego zatrudnionego potwierdza coraz większą kapitałochłonność inwestycji.

Ryc. 3. Wielkość inwestycji zagranicznych we Francji i inwestycji francuskich za granicą w latach 1990-2008 oraz kapitałochłonność inwestycji zagranicznych w latach 1993-2007
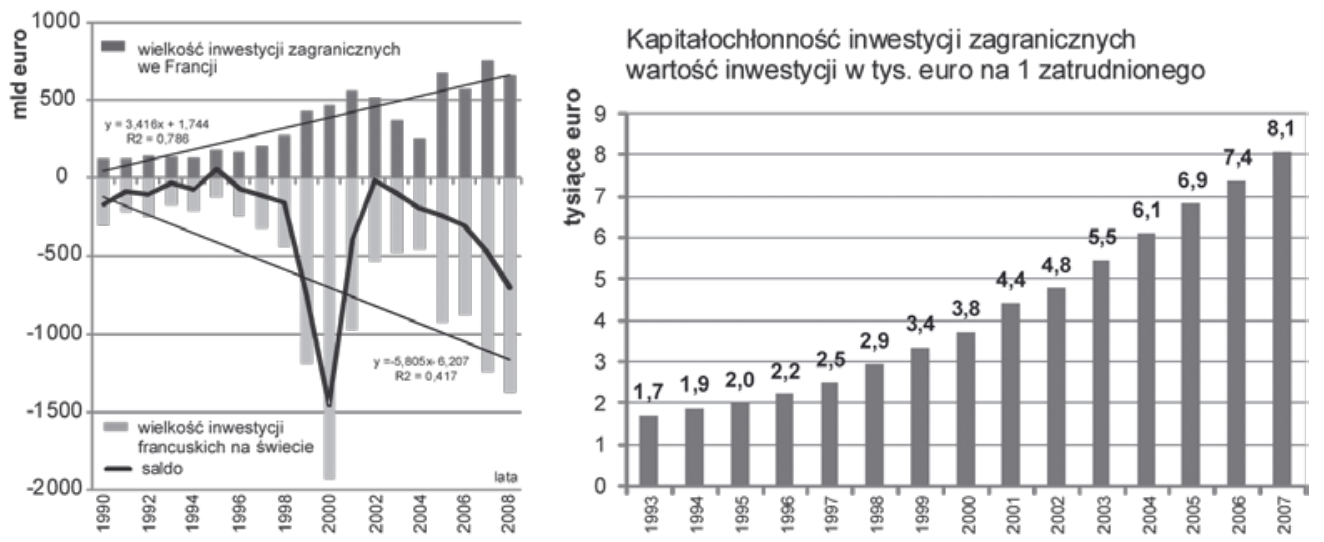

Źródło: opracowanie własne na podstawie danych Banque de France.

Jednym z efektów procesów globalizacji jest stopniowe powiększanie sfery oddziaływań gospodarczych poszczególnych państw. W wypadku Francji spośród jej partnerów inwestycyjnych największy udział zarówno pod względem napływu, jak i odpływu inwestycji w 2009 r. mają państwa sąsiadujące, tj. kraje Beneluksu, Niemcy oraz Wielka Brytania (ryc. 4). Wysoki udział tych krajów w wymianie inwestycyjnej ma źródło nie tylko w ich bliskości geograficznej, ale również w dużym stopniu wynika z powiązań i uwarunkowań politycznych, gospodarczych oraz kulturowych. Powiązania te można dostrzec na obszarze całej Europy Zachodniej, a w szczególności w jej najbardziej rozwiniętym gospodarczo regionie, tzw. europejskiego 
banana. Zaznaczyć należy, że udział państw europejskich, w tym głównie unijnych, w wartości inwestycji napływających do Francji i z niej odpływających w obydwu przypadkach maleje. Proces ten jest zapewne także efektem nasilającej się globalizacji rynku światowego oraz nowych możliwości współpracy zagranicznej. Dodatkowo widoczne jest duże zróżnicowanie udziału poszczególnych krajów w wielkości inwestycji. Zjawisko to dotyczy nie tylko odległych partnerów inwestycyjnych Francji, tj. Japonii czy Stanów Zjednoczonych Ameryki, ale odnosi się także do partnerów europejskich.

Ryc. 4. Najważniejsi inwestycyjni partnerzy Francji w UE i na świecie w latach 2007-2008 według wartości inwestycji

A) francuskie inwestycje zagraniczne

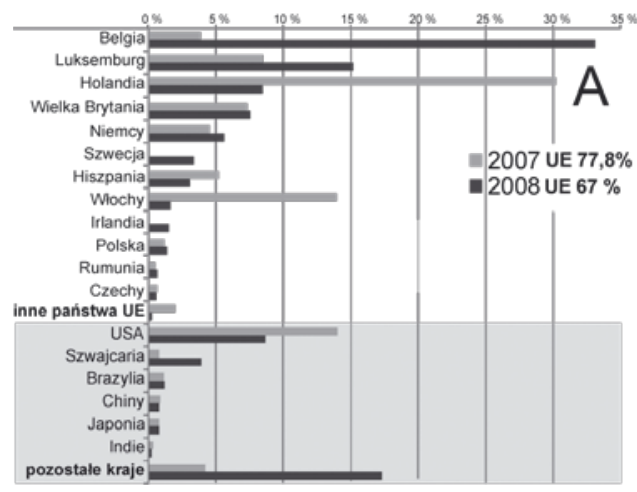

B) inwestycje zagraniczne we Francji

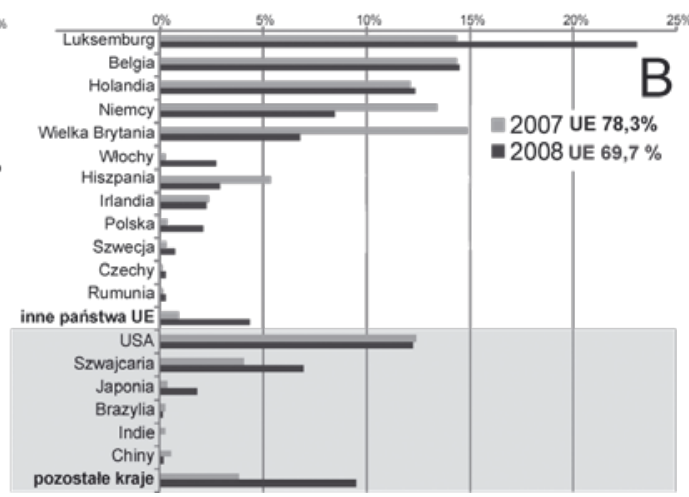

Źródło: opracowanie własne na podstawie danych Banque de France.

Odmienny obraz rozmieszczenia partnerów Francji otrzymujemy przy analizie liczby projektów inwestycyjnych (ryc. 5). Jeśli chodzi o liczbę inwestycji, a nie ich wartość - w czołówce inwestorów znajdują się najbardziej rozwinięci gospodarczo partnerzy Francji: Niemcy i Stany Zjednaczane. Następne w kolejności są państwa europejskie, tj. Włochy, Hiszpania, Wielka Brytania, Szwajcaria, Belgia i Holandia oraz w mniejszym stopniu Szwecja i Dania. To właśnie te państwa odnotowały w 2008 r. w stosunku do roku poprzedniego wyraźny wzrost liczby inwestycji (najwięcej Dania, która zwiększyła przeszło o 70\% liczbę inwestycji we Francji). Spośród partnerów pozaeuropejskich wysoki wzrost odnotowały Indie oraz w mniejszym stopniu Kanada i Chiny.

Zmiany w rozmieszczeniu zagranicznych inwestorów są wynikiem coraz większej ekspansywnej polityki gospodarczej krajów azjatyckich. Natomiast w przypadku innego ważnego partnera Francji - Kanady, wysoki udział inwestycji można tłumaczyć istnieniem powiązań społeczno-gospodarczych wynikających z uwarunkowań historycznych, przeniesionych na współczesne więzi kulturowe. Ten ostatni czynnik wydaje się odgrywać ważną rolę w kwestiach lokowania inwestycji nie tylko w samej Europie, o czym wspomniano wcześniej, ale też inwestycji obejmujących o wiele większy obszar kultury zachodniej². Jednym z podstawowych uwarunkowań w kontaktach handlowych jest możliwość porozumienia (zrozumienia), nie tylko w sferze kulturowej, lecz i lingwistycznej. Tłumaczy to duży udział inwestorów zagranicznych

\footnotetext{
${ }^{2}$ Przykładem może być sukces gospodarczy Irlandii, do którego przyczynili się także Amerykanie irlandzkiego pochodzenia, inwestujący w ojczyźnie przodków w latach 1997-2003 prawie 250 mld euro.
} 
pochodzących z częściowo francuskojęzycznych krajów: Belgii, Luksemburga, Szwajcarii czy Kanady, lecz także wyjaśnia wysoki udział anglojęzycznych Indii i częściowo japońskojęzycznych Chin (prowincja Dalian) w gospodarce światowej. Oczywiście wyżej wspomniane czynniki wpływające na wybór miejsca inwestycji odgrywają największa rolę jedynie w przypadkach, w których konkurencja kosztowa jest najmniejsza, natomiast decydującą rolę zaczynają odgrywać tzw. czynniki miękkie, tj. kapitał ludzki, przyjazna aura dla przedsiębiorców lub dobry klimat inwestycyjny. Przykładem tego typu działań są inwestycje w sektorze szeroko rozumianych usług dla biznesu (Business Process Outsourcing - BPO). Są to usługi zarówno z zakresu księgowości i finansów, jak i usługi typu IT oraz z zakresu prac badawczo-rozwojowych. To właśnie działalność naukowo-badawcza, prowadzona w oparciu o kapitał ludzki, przez wielu badaczy uważana jest obecnie za główny stymulant rozwoju gospodarczego (m.in. Skrzypek 2007; Babiak 2008; Chojnicki, Czyż 2008; Goldberg, Goddard, Kuriakose 2008; Markowski 2008; Borowiec 2008). Gospodarka oparta na wiedzy (GOW) funkcjonuje dzięki wykorzystaniu zasobów wiedzy oraz rozwojowi technologii. Innym ważnym kryterium GOW jest zdolność do generowania i dyfuzji innowacji, które prowadzą do modernizacji i wzrostu konkurencyjności gospodarki.

Ryc. 5. Najważniejsi inwestycyjni partnerzy Francji w UE i na świecie w latach 2007-2008 według wartości inwestycji

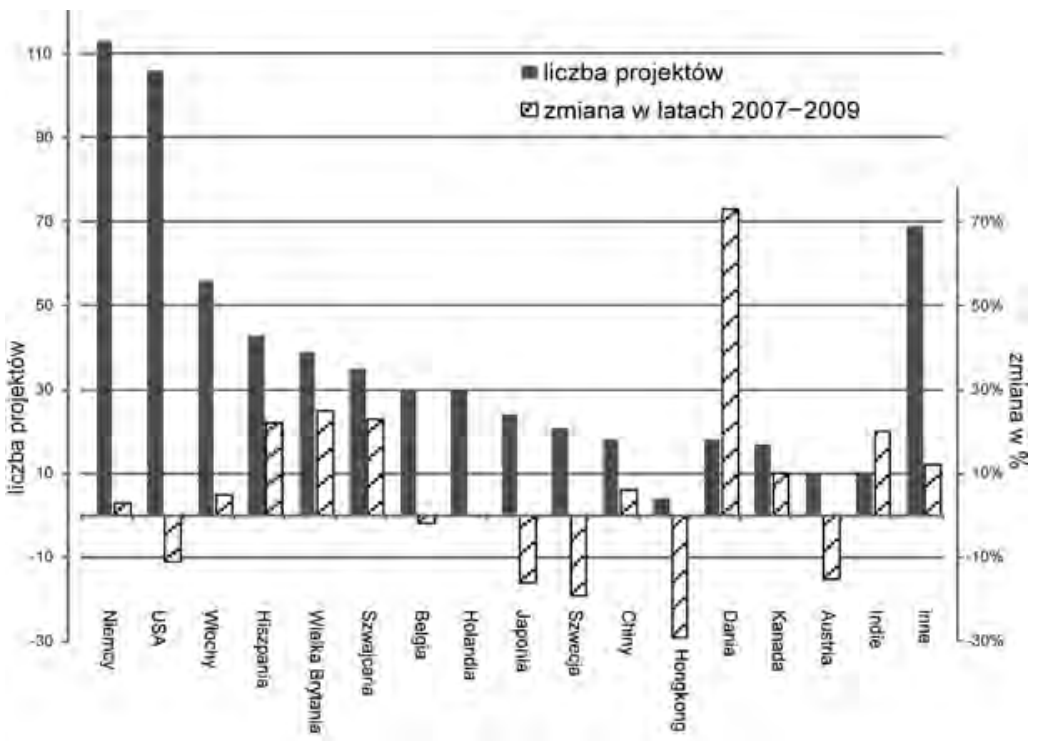

Źródło: opracowanie własne na podstawie danych Banque de France.

Następnym ważnym wskaźnikiem świadczącym o wielkości i znaczeniu inwestycji dla danego kraju czy regionu jest liczba miejsc pracy generowanych przez BIZ. Analizując zatem powyższe wartości, można stwierdzić, że od lat 90. XX w. inwestycje zagraniczne we Francji odnotowały dwie prawidłowości (ryc. 6). Po pierwsze nastąpił ogólny wzrost liczby inwestycji zagranicznych przy jednoczesnym powolnym spadku liczby miejsc pracy generowanych przez inwestycje zagraniczne. Po drugie - niejako wynikiem wcześniejszego procesu był wzrost kosztów poniesionych na powstanie nowych miejsc pracy oraz obniżenie wielkości nakładów na pojedyncze przedsięwzięcia inwestycyjne. Źródła tych procesów należy upatrywać zarówno 
w coraz większej automatyzacji produkcji, jak i w malejącym udziale inwestycji w sektorze przemysłu, który jednakże wciąż stanowi główny sektor inwestycji zagranicznych. Odwołując się zatem do wcześniejszych spostrzeżeń, można domniemywać, że kraje rozwinięte gospodarczo, tj. Niemcy czy USA, inwestują we Francji w sferze usług i IT, co wpływa na obniżenie wielkości inwestycji i ograniczenie zatrudnienia generowanego przez BIZ. Należy tu wspomnieć, że podmioty gospodarcze działające w sektorze B+R charakteryzują się małym zatrudnieniem (Lundin, Sjöholm, Qian 2006). Szczególne widoczne jest to w przypadku przedsiębiorstw z branży biotechnologicznej. We Francji w 2000 r. średnia wielkość firm w tej branży nie przekroczyła średniego zatrudnienia ponad 50 osób (Mangematin, Lemarié, Catherine 2001).

Ryc. 6. Liczba projektów i miejsc pracy generowanych przez BIZ we Francji w latach 1993-2009
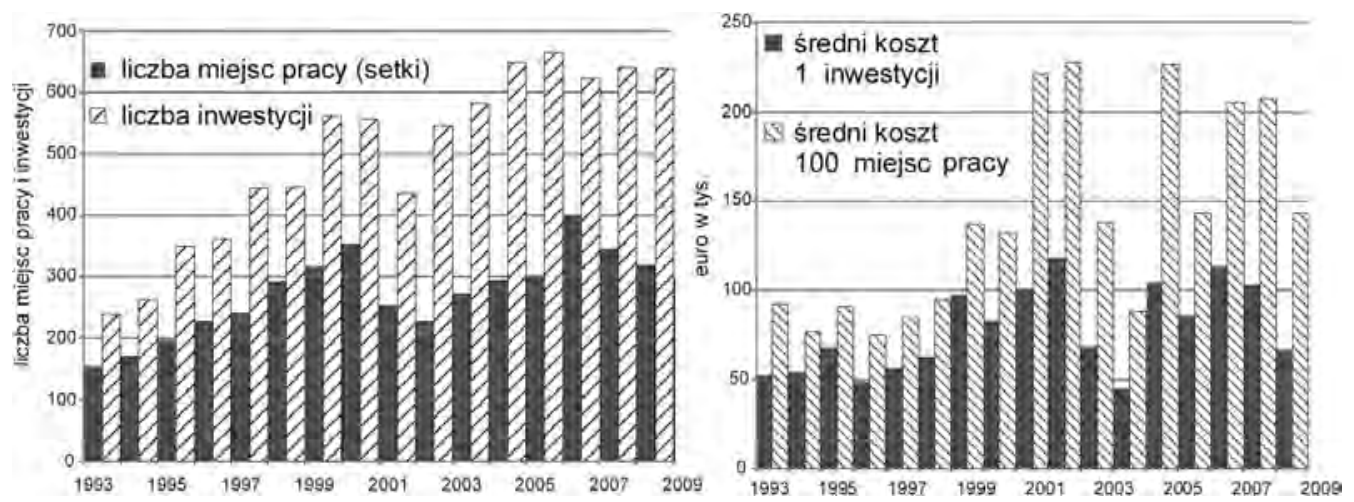

Źródło: opracowanie własne na podstawie danych Banque de France.

Powyższe stwierdzenie, odnoszące się do rodzaju inwestycji zagranicznych podejmowanych we Francji w ostatnich latach, potwierdza zestawienie liczby BIZ ze względu na aktywność gospodarczą (ryc. 7). W badanym okresie największe zatrudnienie na jedną inwestycję generowały projekty inwestycyjne $\mathrm{w}$ grupie produkcji, handlu i usług oraz logistyki, podczas gdy inwestycje w sektorze związanym z zarządzaniem i sektorze innowacji generują średnio o 20 etatów mniej. Ponadto tylko w wymienionych grupach nastąpił w latach 2007-2008 wzrost liczby inwestycji o przeszło 10 punktów procentowych. Jednakże podkreślić należy, że w dalszym ciągu (ze względu na udział w liczbie projektów) na pierwszym miejscu znajduje się produkcja, a następnie usługi, zarówno dla przedsiębiorstw, jak i dla ludności. Najmniejszy udział liczby inwestycji (poniżej 10\%) w 2009 r. odnotowano w dziale logistyki i w sektorze $\mathrm{B}+\mathrm{R}$.

Powyższe zmiany w strukturze napływu inwestycji zagranicznych w odniesieniu do wzrostu udziału inwestycji w usługach i w sektorze $\mathrm{B}+\mathrm{R}$ potwierdza malejący udział projektów inwestycyjnych związanych z infrastrukturą trwałą, tzw. inwestycji trwałych, które zazwyczaj są inwestycjami nowymi, tzw. greenfield (ryc. 8). W latach 1993-2009 wzrósł udział (z około 30 do $70 \%$ ) inwestycji doraźnych, które nie mają wymiaru trwałej infrastruktury materialnej. Świadczy to o zainteresowaniu inwestorów zagranicznych głównie kapitałem ludzkim oraz czynnikami pozakosztowymi inwestycji.

Wobec przedstawionych faktów rodzi się pytanie: czy wyżej zaznaczone procesy zachodzą z takim samym natężeniem na terenie całej Francji, czy też istnieje regionalne zróżnicowanie natężenia inwestycji zagranicznych? 
Analizując regionalne zróżnicowanie liczby realizowanych inwestycji zagranicznych w latach 2007-2009, można zauważyć wyraźną dominację regionu Île-de-France, przyciągającego ok. 30\% wszystkich projektów. O połowę mniej inwestycji przyciąga region Rhône-Alpes, podczas gdy pozostałe regiony posiadają udział poniżej 5\% (ryc. 9).

Ryc. 7. Inwestycje zagraniczne we Francji wg aktywności gospodarczej w 2009 r.

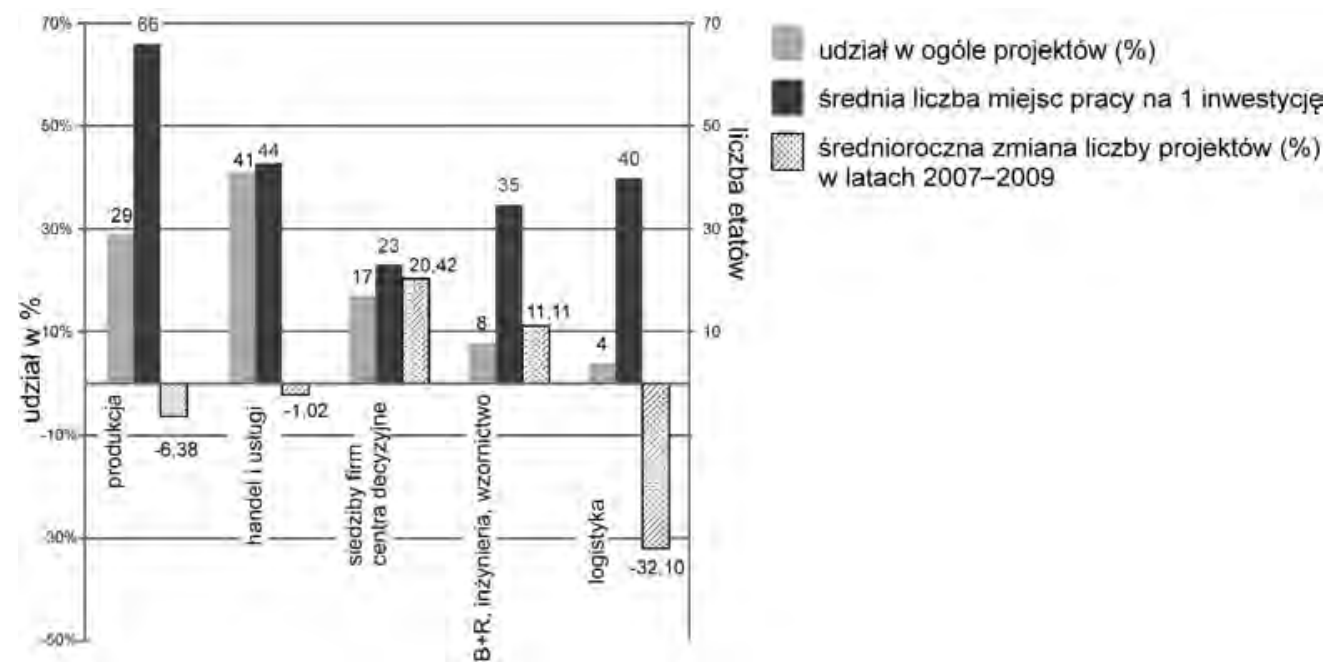

Źródło: opracowanie własne na podstawie danych Banque de France.

Ryc. 8. Rodzaje inwestycji zagranicznych we Francji w latach 1993-2009

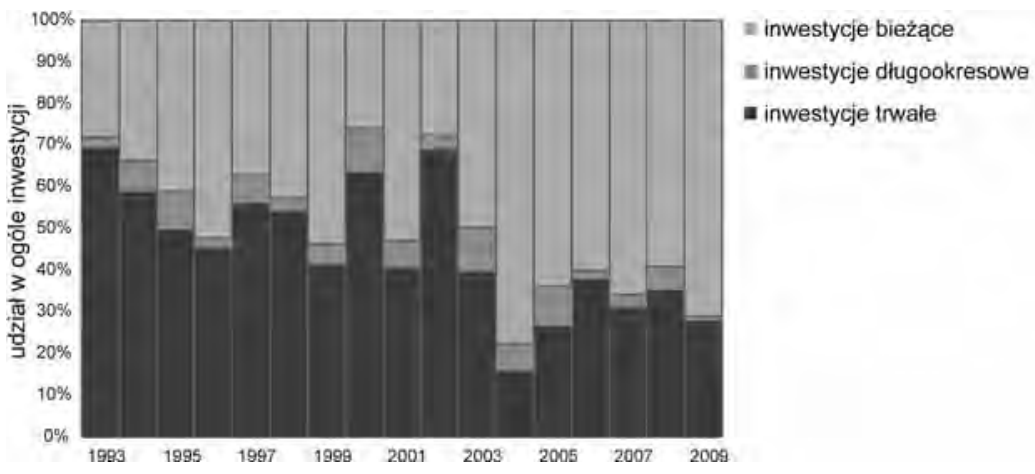

Źródło: opracowanie własne na podstawie danych Banque de France.

Analizując średni udział inwestycji zagranicznych we Francji dla lat 2007-2009 (wybrano wartości średnie, aby wykluczyć jednostkowe, skokowe zmiany analizowanych zjawisk) w układzie regionalnym, można wyróżnić cztery regiony o największym napływie inwestycji zagranicznych: Paryski, Południowo-Wschodni (Rhône-Alpes i Provence-Alpes-Côte d'Azur), Pirenejski i Północny (Nord-Pas-de-Calais). Największy napływ inwestycji do tych regionów związany jest z ogólnym wysokim poziomem rozwoju gospodarczego oraz obecnością największych metropolii Francji, m.in. Paryża, Lyonu, Tuluzy i Lille. Dowodzi to z jednej strony 
strategicznej roli metropolii w przyciąganiu inwestycji zagranicznych ${ }^{3}$, a z drugiej - pośrednio świadczy o wspomnianej dominacji innowacyjności w inwestycjach. To właśnie wielkie aglomeracje jako centra naukowe 4 i badawcze stanowią główny czynnik przyciągający współcześnie inwestycje. Potwierdza to Światowy Raport Inwestycyjny UNCTAD, który stwierdza, że zjawiska stymulujące postęp globalizacji zmieniają sposób, w jaki podmioty gospodarcze, w tym głównie korporacje międzynarodowe, decydują o dokonaniu inwestycji zagranicznych. Inwestorzy w coraz większym stopniu poszukują miejsc, których atrakcyjność wyraża się w czynniku ludzkim, czyli tzw. aktywach wytworzonych, obejmujących cały szereg zjawisk, od zaawansowania technologicznego do wykwalifikowanej siły roboczej. Technologia i innowacyjność zyskały status kluczowych dla konkurencyjności inwestycyjnej regionów (WIR 1998).

Biorąc pod uwagę liczbę inwestycji w przeliczeniu na 1000 zatrudnionych, możemy potwierdzić wcześniejszy układ przestrzenny w rozmieszczeniu inwestycji zagranicznych we Francji. W ujęciu tym traci region Paryża na rzecz uprzemysłowionych regionów zachodnich Francji, głównie Lotaryngii i Alzacji oraz Szampanii. Najniższymi wartościami odznaczają się regiony od Bretanii na zachodzie po Limousin w Masywie Centralnym.

Ryc. 9. Regionalne zróżnicowanie liczby BIZ we Francji w latach 2007-2009

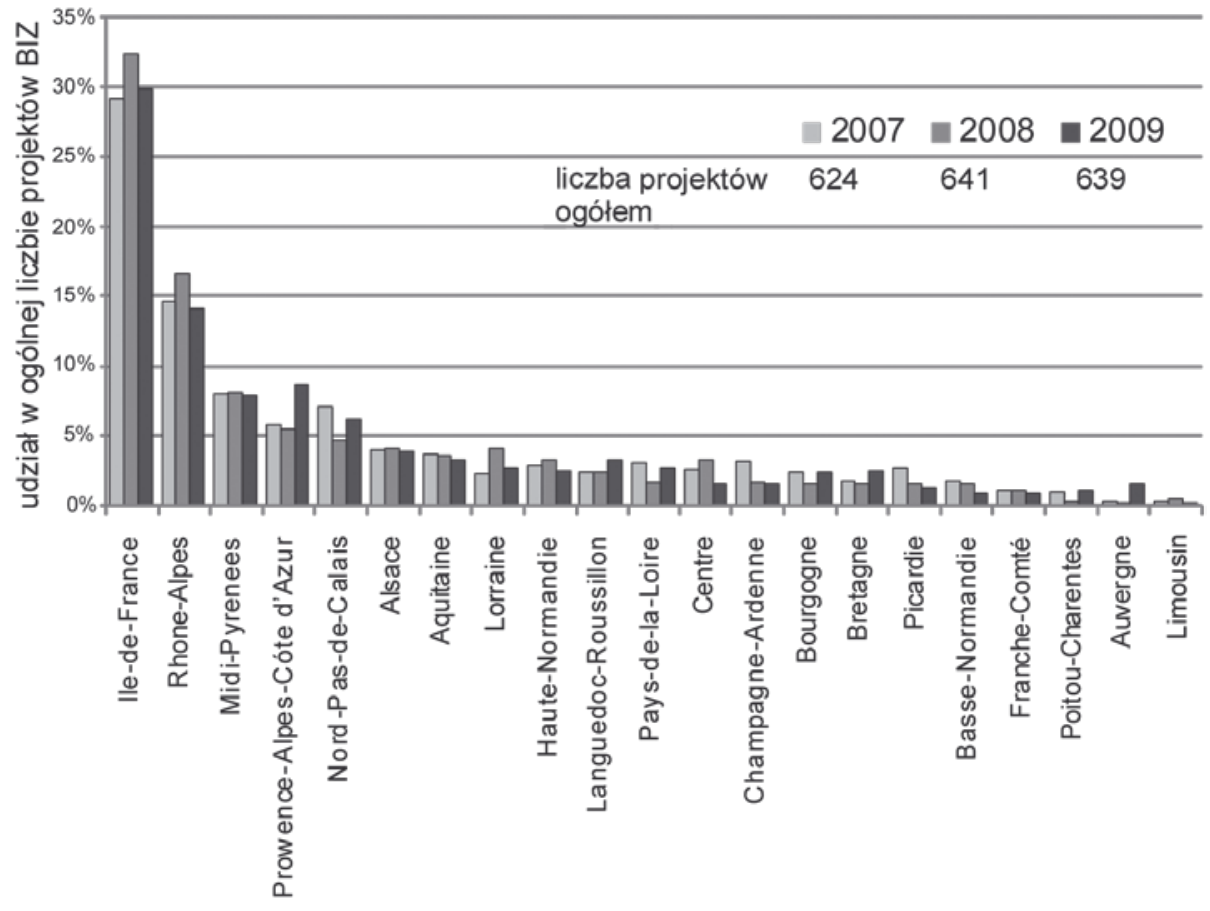

Źródło: opracowanie własne na podstawie danych Banque de France.

\footnotetext{
${ }^{3}$ Szerzej o znaczeniu metropolii w odniesieniu do napływu inwestycji pisali m.in. Domański (2008) oraz Domański, Guzik, Gwosdz (2000).

${ }^{4} \mathrm{O}$ znaczeniu miast w strukturze szkolnictwa wyższego Francji pisali M. Borowiec, S. Dorocki, Procesy transformacji ośrodków akademickich jako czynnik podnoszenia jakości zasobów kapitału ludzkiego w uktadach regionalnych Francji (w druku).
} 
Ryc. 10. Średnia liczba inwestycji zagranicznych w regionach Francji w latach 2007-2009

A - ogółem, B - na 1000 zatrudnionych

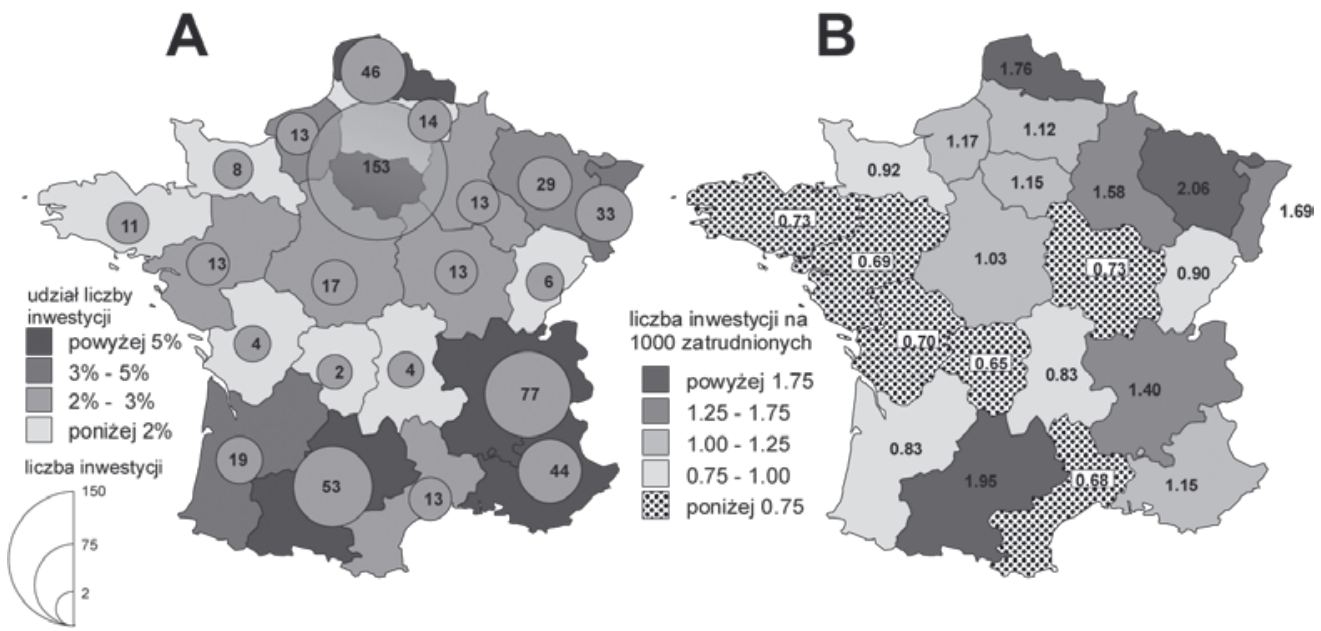

Źródło: opracowanie własne na podstawie danych Banque de France.

Podobny obraz przestrzennego rozkładu inwestycji zagranicznych we Francji otrzymujemy również, analizując udział regionów według liczby stworzonych miejsc pracy (ryc. 11). W tym ujęciu dominacja regionu paryskiego jest jeszcze większa. Region Île-de-France skupia ponad $25 \%$ zatrudnionych w przedsięwzięciach inwestycyjnych, podczas gdy następne według wielkości regiony Rhône-Alpes, Akwitania, Midi-Pyrénées i Nord-Pas-de-Calais skupiają od 5 do $10 \%$ zatrudnionych. W pozostałych regionach udział zatrudnionych w inwestycjach zagranicznych jest podobny, a istniejące różnice ulegają powolnemu zmniejszeniu.

Ryc. 11. Regionalne zróżnicowanie liczby miejsc pracy powstałych dzięki inwestycjom zagranicznym we Francji w latach 2007-2009

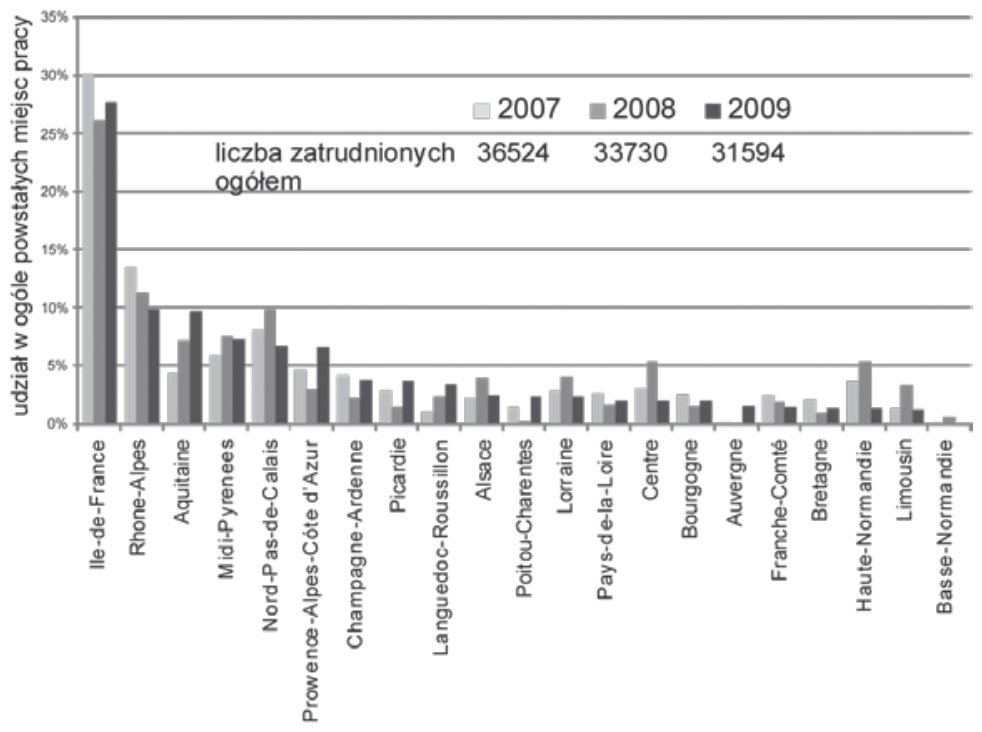

Źródło: opracowanie własne na podstawie danych Banque de France. 
Innym wskaźnikiem poziomu inwestycji zagranicznych jest liczba miejsc pracy generowanych przez inwestycje zagraniczne oraz wartość ta w stosunku do ogółu zatrudnionych. W obydwu przypadkach przedstawione prawidłowości regionalne zostają powielone. Dotyczy to głównie dominacji według powyższych wartości regionów najbardziej rozwiniętych ekonomicznie (ryc. 12). Jedynie według liczby miejsc pracy w BIZ na 1000 miejsc ogółem można zauważyć wzrost znaczenia regionów przemysłowych, szczególnie regionu Midi-Pyrénées, gdzie na 1000 miejsc pracy są 2,12 miejsca wygenerowane przez inwestycje zagraniczne. $\mathrm{W}$ pozostałych regionach o dużym udziale zatrudnionych w projektach inwestycyjnych, $\mathrm{tj}$. Lotaryngia, Champagne-Ardenne, Nord-Pas-de-Calais, wartość ta wynosi około 1,7, podczas gdy w rozwiniętych regionach Île-de-France czy Rhône-Alpes badana wartość oscyluje wokół 1,5. Można stwierdzić, że najwięcej miejsc pracy powstałych dzięki inwestycjom zagranicznym we Francji w latach 2007-2009 znajduje się na północy Francji (głównie w regionach północno-zachodnich), południowym wschodzie i południowym zachodzie, podczas gdy w pozostałych regionach wartość ta nie przekracza jednego etatu i jest najniższa w regionie Limousin $(0,29)$ w Masywie Centralnym.

Ryc. 12. Regionalne zróżnicowanie liczby miejsc pracy powstałych dzięki inwestycjom zagranicznym we Francji w latach 2007-2009

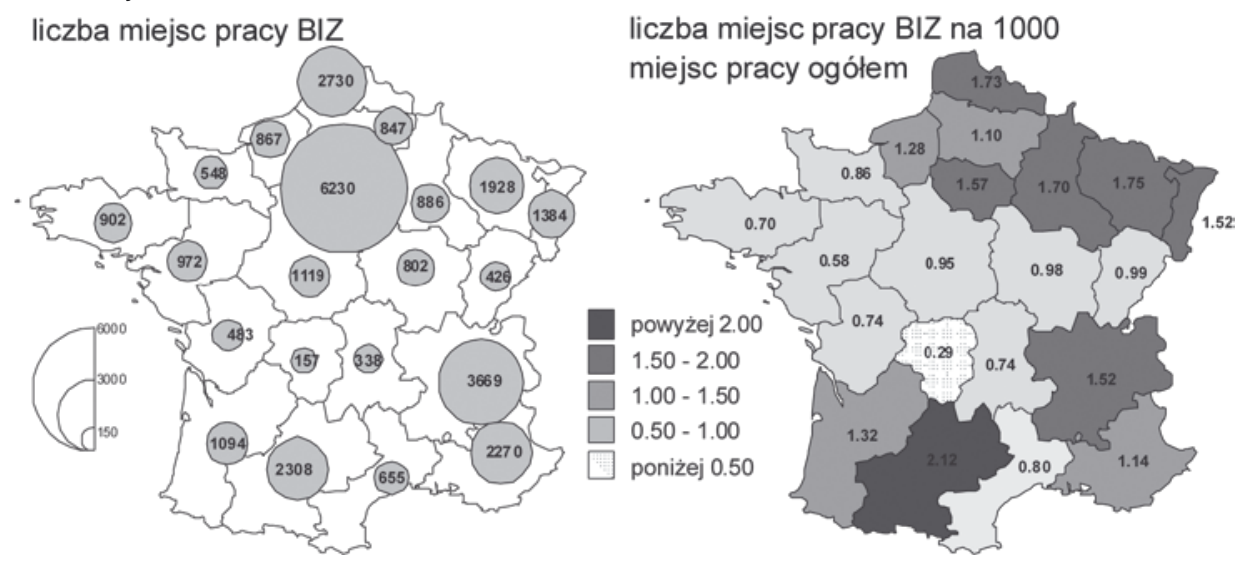

Źródło: opracowanie własne na podstawie danych Banque de France.

Odmienny obraz Francji otrzymujemy w analizie średniorocznej zmiany liczby miejsc pracy stworzonych dzięki BIZ na 1000 miejsc ogółem we Francji w latach 2007-2009 (ryc. 13). Największą dynamiką zmian (ponad 100\%) wykazują się regiony o niskich lub średnich wartościach inwestycji, tj. Owernia, Poitou-Charentes, Dolna Normandia i Szampania. Natomiast spadek miejsc pracy w BIZ na 1000 miejsc ogółem odnotowały regiony zarówno o dużym napływie inwestycji, tj. Rhône-Alpes, Midi-Pyrénées, Lotaryngia, jak i regiony o małym znaczeniu inwestycyjnym, tj. Kraina Loary czy Burgundia. Również w tym przypadku zauważone zmiany mogą mieć swe korzenie w zmianie struktury inwestycyjnej przejawiającej się w odejściu od tradycyjnego przemysłu ku sferze usług i przemysłu high-tech. Potwierdza się także stawiana wcześniej teza o regionalnym wyrównywaniu poziomu zatrudnienia, o czym może świadczyć największy wzrost zatrudnienia odnotowany przez najmniej rozwinięte gospodarczo regiony Francji. Z drugiej strony świadczy to o lokalizacji w tych regionach inwestycji związanych z dużym zatrudnieniem, co zwiększa geograficzne zróżnicowanie kapitału ludzkiego, pogłębiając strukturalny dystans regionów. 
Ryc. 13. Średnioroczna zmiana liczby miejsc pracy stworzonych przez BIZ na 1000 miejsc pracy ogółem we Francji w latach 2007-2009

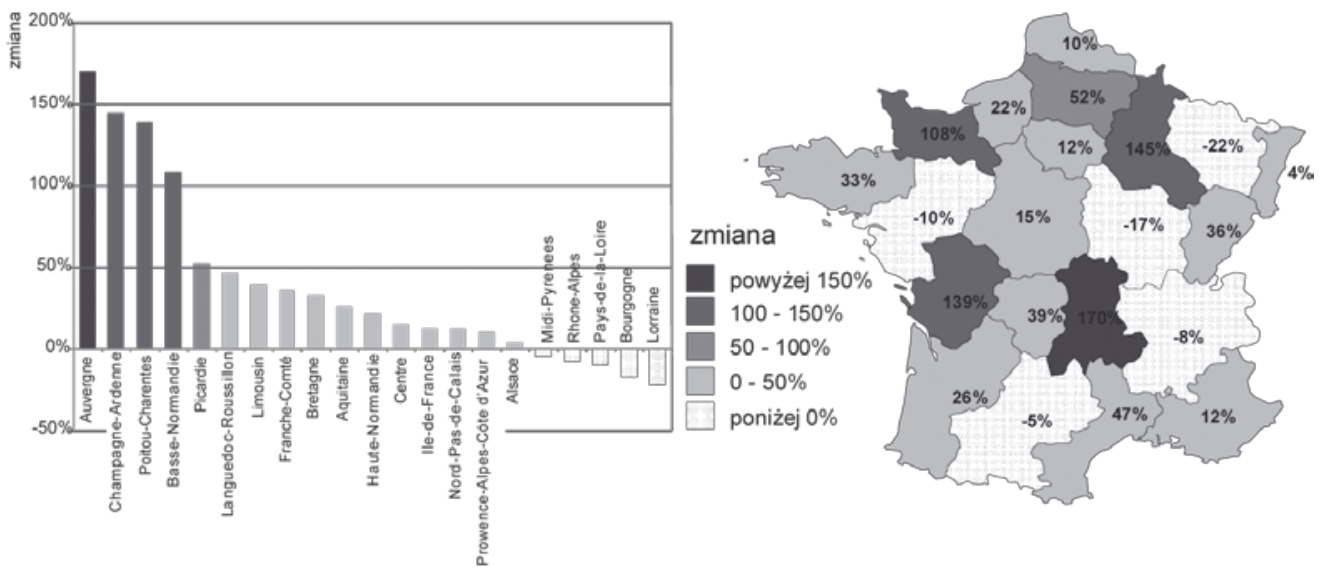

Źródło: opracowanie własne na podstawie danych Banque de France.

Innym wskaźnikiem znaczenia inwestycji zagranicznych jest średnia wielkość stworzonych miejsc pracy przypadających na jeden projekt inwestycyjny (ryc. 14). Wskaźnik ten, jak wspomniano powyżej, można odnieść do rodzaju dokonanej inwestycji. Inwestycje, które tworzą dużo miejsc pracy, to przede wszystkim inwestycje w działalność produkcyjną, w tym głównie przemysłową. Inwestycje takie miały miejsce we Francji w okresie 2007-2009 w regionach peryferyjnych względem centrów gospodarczych, tj. w regionie Akwitanii, Pikardii, Szampanii, Dolnej Normandii oraz Franche-Comté, Północnym i Centre. Średnia liczba miejsc przypadających na jedną inwestycję wahała się tam od ok. 118 etatów w Akwitanii do ok. 70 w Regionie Centralnym. Natomiast inwestycje w MŚP były skupione w rozwiniętych regionach południowych i południowo-wschodnich, Alzacji i Lotaryngii oraz w Bretanii.

Jednakże pomimo tych regionalnych różnic we Francji można zauważyć dużą zależność między udziałem poszczególnych jednostek administracyjnych w liczbie BIZ i stworzonych przez nie miejsc pracy (ryc. 15). Jedynie dwa najbardziej rozwinięte regiony: Île-de-Francei Rhône-Alpes wykazują wyraźną przewagę inwestycji w MŚP, które jak można wywnioskować z poprzednich danych w większości są skupione w sektorze innowacyjnym $(B+R)$.

Na koniec rozważań nad wielkością i regionalnym zróżnicowaniem inwestycji zagranicznych we Francji podjęto próbę odpowiedzi na pytanie, jakie czynniki wpływają na wielkość inwestycji. Jako kanwę rozważań przyjęto wypowiedź prezydenta Francji Nicolasa Sarkozy’ego z 29 lipca 2010 r. Prezydent stwierdził, że „Francja dysponuje licznymi atutami: bardzo dynamiczną demografią, wysokiej jakości siłą roboczą, najlepszą infrastrukturą w Europie; jest krajem doceniającym zmysł przedsiębiorczości, o efektywnie działających firmach" "Na podstawie powyższej wypowiedzi przyjęto, że głównymi atutami Francji przyciągającymi zagranicznych inwestorów jest wielkość i dynamika rynku, gęstość i wydajności infrastruktury, poziom i kwalifikacje pracowników oraz jakość życia. W celu określenia wpływu powyższych czynników na wielkość inwestycji zestawiono 25 zmiennych opisujących trzy wybrane czynniki, tj. rynek, kwalifikacje (edukacja) i infrastrukturę (tab. 1).

$\overline{{ }^{5} \mathrm{http} / / / w w w . a m b a f r a n c e-p l} . o r g /$ france_pologne/spip.php?article4006 (stan na dzień 24.10.2010). 
Ryc. 14. Wielkość inwestycji wg stworzonych miejsc pracy we Francji w latach 2007-2009
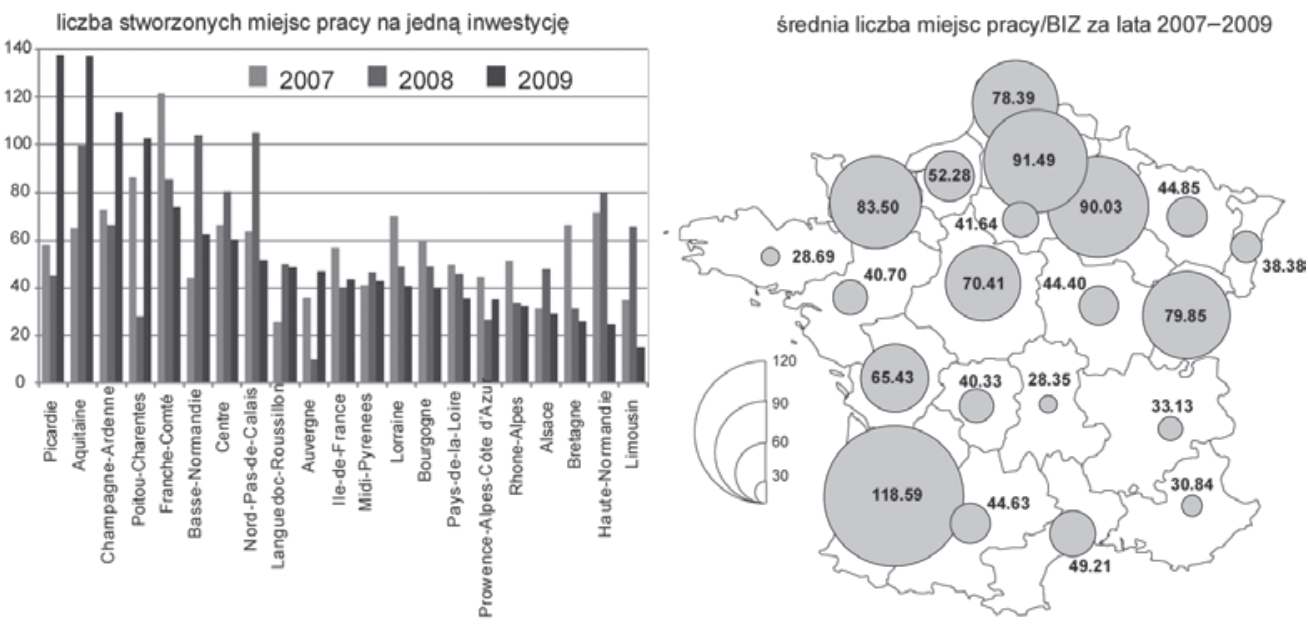

Źródło: opracowanie własne na podstawie danych Banque de France.

Ryc. 15. Wielkość inwestycji według stworzonych miejsc pracy we Francji w latach 2007-2009

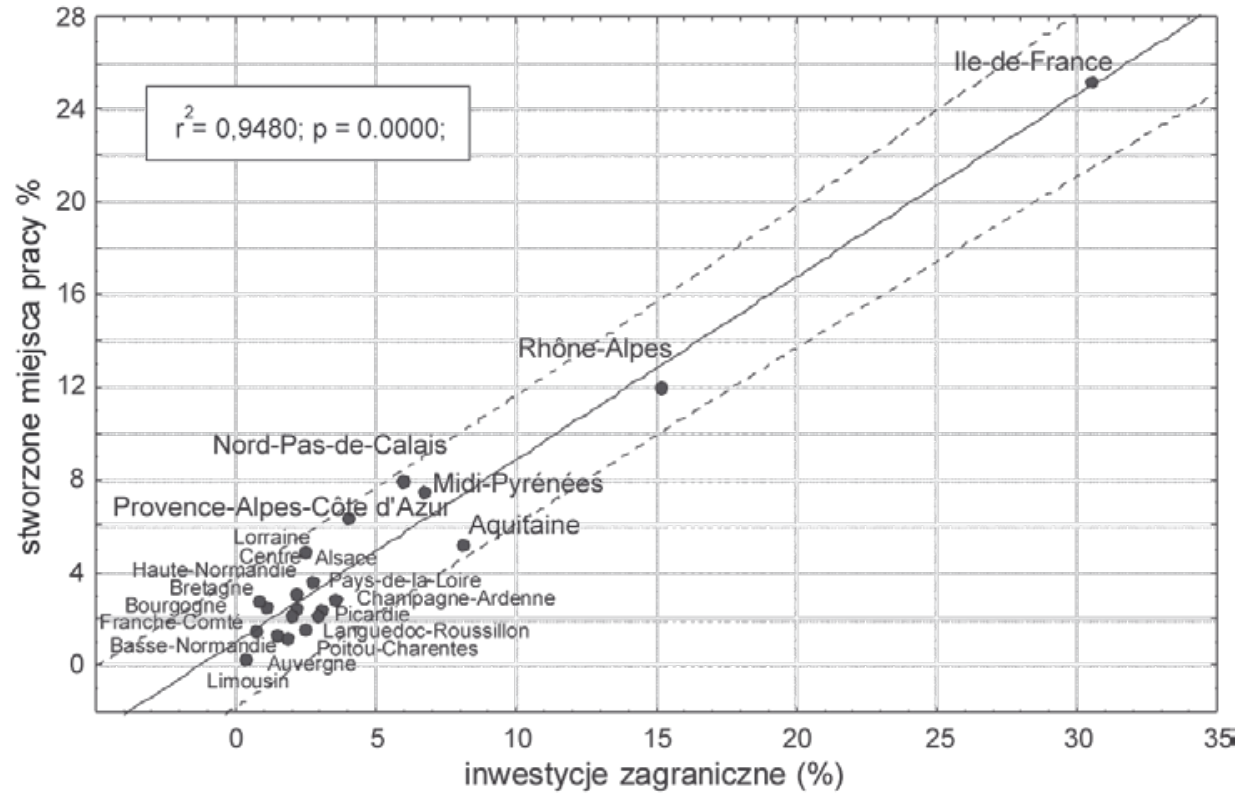

Źródło: opracowanie własne na podstawie danych Banque de France.

Następnie, wykorzystując korelację kanoniczą, dokonano szczegółowego zestawienia wszystkich wyszczególnionych w powyższym tekście cech oraz przyjętych wskaźników obrazujących sytuację społeczno-ekonomiczną regionów Francji. W dalszej analizie ograniczono się do 19 istotnych statystycznie zmiennych. Należy podkreślić, że dokonane zestawienie jest tylko orientacyjną próbą określenia powyższych zależności. Pełne badanie wymaga bowiem powiększenia zakresu zmiennych i ich różnorodności. 
Tab. 1. Zależność pomiędzy wielkością inwestycji zagranicznych we Francji w 2009 r. a wybranymi czynnikami charakteryzującymi warunki regionalne w 2006 r.

\begin{tabular}{|c|c|c|}
\hline \multirow[t]{2}{*}{ Zmienne } & $\begin{array}{c}\text { Liczba } \\
\text { inwestycji }\end{array}$ & $\begin{array}{l}\text { Liczba zatrudnio- } \\
\text { nych w inwestycjach } \\
\text { zagranicznych }\end{array}$ \\
\hline & \multicolumn{2}{|c|}{ Rynek R:0,95 p = 0,00622 } \\
\hline korelacja & $\mathbf{0 , 9 4} p=0,00019$ & $\mathbf{0 , 9 5} \mathrm{p}=0,00008$ \\
\hline PKB na osobę & 0,89 & 0,91 \\
\hline wielkość zarobków na 1 osobę & 0,89 & 0,90 \\
\hline \multirow[t]{2}{*}{ wartość dodana na 1 pracującego } & 0,92 & 0,94 \\
\hline & \multicolumn{2}{|c|}{ Kwalifikacje R:0,97 p = 0,00001 } \\
\hline korelacja & $\mathbf{0 , 9 6} \mathrm{p}=0,00000$ & $\mathbf{0 , 9 4} \mathrm{p}=0,00000$ \\
\hline wskaźnik HRST & 0,79 & 0,80 \\
\hline studenci na 1000 osób & 0,81 & 0,80 \\
\hline klasa kreatywna (wg R. Florydy): & 0,93 & 0,92 \\
\hline - super kreatywni (core) & 0,92 & 0,90 \\
\hline - profesjonaliści (professionals) & 0,92 & 0,92 \\
\hline \multirow[t]{2}{*}{ - twórcy (bohemians) } & 0,86 & 0,87 \\
\hline & \multicolumn{2}{|c|}{ Infrastruktura R:0,98 $\mathrm{p}=0,00039$} \\
\hline korelacja & $\mathbf{0 , 9 6} \mathrm{p}=0,00003$ & $\mathbf{0 , 9 8} \mathrm{p}=0,00001$ \\
\hline wydatki na $\mathrm{B}+\mathrm{R}$ oraz rozwój infrastruktury & 0,93 & 0,94 \\
\hline \multicolumn{3}{|l|}{ liczba zatrudnionych w stosunku do ogółu zatrudnionych w: } \\
\hline - usługach & 0,85 & 0,86 \\
\hline - obsłudze finansowej & 0,76 & 0,79 \\
\hline - obsłudze indywidualnej ludności & 0,82 & 0,83 \\
\hline - obsłudze przedsiębiorstw & 0,94 & 0,94 \\
\hline - usługach w dziale nieruchomości & 0,79 & 0,77 \\
\hline - szkolnictwie, służbie zdrowia, usługach socjalnych & $-0,65$ & $-0,65$ \\
\hline - administracji & 0,08 & 0,07 \\
\hline $\begin{array}{l}\text { udział zakładów usługowych w ogóle podmiotów } \\
\text { gospodarczych }\end{array}$ & 0,94 & 0,95 \\
\hline
\end{tabular}

Źródło: opracowanie własne.

Na podstawie otrzymanych wartości określających siłę zależności (lub współwystępowania) można stwierdzić, że na wielkość inwestycji wpływa w największym stopniu infrastruktura (R:0,98), a spośród analizowanych zmiennych poziom usług $(0,94)$, w tym usług dla przedsiębiorstw. Zaznaczyć należy, że tak wysoka współzależność może wynikać z ogólnego rozwoju 
ekonomicznego regionów, w których odnotowano zarówno duży napływ inwestycji zagranicznych, jak i znaczny udział sektora usług, co jest charakterystyczne dla rozwiniętych gospodarek. W odniesieniu do struktury inwestycji poziom infrastruktury bardziej wpływa na inwestycje kapitałochłonne (inwestycje generujące duże zatrudnienie) niż na inwestycje skierowane do sektora MŚP. Należy zwrócić uwagę na to, że w regionach charakteryzujących się wysokim udziałem zatrudnionych w szkolnictwie oraz służbie zdrowia i usługach socjalnych jest zauważalny najmniejszy napływ inwestycji. Nie mniej ważnym czynnikiem stymulującym napływ inwestycji zagranicznych jest kapitał ludzki (R:0,97). W tym przypadku wykształcenie ludności regionu wpływa w większym stopniu na ilość inwestycji niż na ich rozmiar wyrażony liczbą stworzonych miejsc pracy. Spośród analizowanych zmiennych największy wpływ na wielkość inwestycji ma udział klasy kreatywnej ${ }^{6}$, natomiast mniejszy udział studentów w ogóle ludności lub wskaźnik HRST ${ }^{7}$. Wskazuje to na szczególne znaczenie jakości kapitału ludzkiego w kwestii przyciągania inwestycji i rozwoju gospodarczego. Natomiast wielkość rynku odgrywa najmniejsze znaczenie spośród analizowanych czynników.

W podsumowaniu przeprowadzonych badań można stwierdzić, że w analizowanym okresie znaczenie Francji w globalnym systemie inwestycji zagranicznych stale wzrasta, a jej kontakty w coraz większym stopniu wykraczają poza Europę. Inwestycje zagraniczne lokowane we Francji to głównie projekty związane z produkcją (rozwijający się szybko sektor wysokich technologii) oraz usługami. Świadczą o tym wzrastające koszty inwestycji, malejące zatrudnienie generowane przez inwestycje oraz malejący udział inwestycji trwałych. Inwestycje lokalizowane są w najbardziej rozwiniętych gospodarczo regionach (Region Paryża, Region Północny oraz Region Rodańsko-Alpejski i Środkowo-Pirenejski). Ważnym czynnikiem wydaje się również obecność w tych regionach metropolii. Spośród wszystkich regionów wyraźną przewagą w napływie inwestycji zagranicznych wyróżnia się region Île-de-France, a na drugim miejscu plasuje się Rhône-Alpes. Inwestycje pracochłonne, związane z przemysłem lokalizowane są w regionach słabiej rozwiniętych, o mniejszym potencjale innowacyjnym. Napływ inwestycji zagranicznych jest determinowany w największym stopniu przez poziom infrastruktury i rozwój usług dla biznesu (BPO) oraz poziom wykształcenia społeczeństwa. Dodatkowo należy zaznaczyć, że inwestycje w sektorze MŚP w większym stopniu są związane z kapitałem ludzkim, podczas gdy inwestycje kapitałochłonne są uwarunkowane infrastrukturą i rynkiem zbytu.

Na koniec należy zauważyć, że wszystkie powyższe procesy mają wymiar światowy i wynikają z coraz większej otwartości rynków światowych, co świadczy o pogłębiającym się procesie globalizacji.

\footnotetext{
${ }^{6}$ Według koncepcji R. Floridy klasa kreatywna to grupa ludzi odpowiedzialnych za sferę innowacji i tworzenie nowych koncepcji i teorii, zarówno w sferze nauki, produkcji, jak i sztuki; grupa ta składa się z naukowców i inżynierów, kadry akademickiej oraz artystów i twórców; szerzej na temat zagadnień klasy kreatywnej i jej funkcji w regionie pisał Stryjakiewicz (2008, 2009), Chantelot, Peres, Virol (2010). ${ }^{7}$ Zasoby ludzkie w sektorze naukowym i technicznym (HRST - Human Resources for Science and Technology).
} 


\section{Literatura}

1. Babiak J. (red.), 2008, Fundusze europejskie a innowacyjność polskiej gospodarki, Wydawnictwo Studio Emka, Warszawa.

2. Bojar E., 2001, Bezpośrednie inwestycje zagraniczne w obszarach słabo rozwiniętych, Wydawnictwo Naukowe PWN, Warszawa.

3. Bojar E., 2008, Bezpośrednie inwestycje zagraniczne (BIZ) w regionach słabo rozwiniętych studium porównawcze Polski i Irlandii. Efekty $i$ wdrożenia, TNOiK, Toruń.

4. Borowiec M., 2008, Rola kapitału ludzkiego w procesie podnoszenia konkurencyjności układów przestrzennych [w:] Przeksztatcenia regionalnych struktur funkcjonalno-przestrzennych, D. Ilnicki, K. Janc (red.), Rozprawy Naukowe Instytutu Geografii i Rozwoju Regionalnego Uniwersytetu Wrocławskiego 3, Instytut Geografii i Rozwoju Regionalnego Uniwersytetu Wrocławskiego, Wrocław, s. 91-98.

5. Brezdeń P., 2006, Uwarunkowania bezpośrednich inwestycji zagranicznych i ich wptyw na umiędzynarodowienie działalności gospodarczej w województwie dolnoślaskim [w:] Międzynarodowe uwarunkowania rozwoju przemystu, Z. Zioło, T. Rachwał (red.), „Prace Komisji Geografii Przemysłu PTG”, nr 8, Komisja Geografii Przemysłu PTG oraz Zakład Przedsiębiorczości i Gospodarki Przestrzennej Instytutu Geografii Akademii Pedagogicznej w Krakowie, Warszawa-Kraków, s. 60-73.

6. Chantelot S., Peres S., Virol S., 2010, The geography of French creative class: An exploratory spatial data analysis, Cahiers du GREThA, n 2010-16, Université Montesquieu Bordeaux, France.

7. Chojnicki Z., 1999, Podstawy metodologiczne i teoretyczne geografii, Bogucki Wyd. Nauk., Poznań.

8. Chojnicki Z., Czyż T., 2008, Gospodarka oparta na wiedzy w regionach metropolitalnych i aglomeracjach miejskich $w$ Polsce [w:] Rola polskich aglomeracji wobec wyzwań strategii lizbońskiej, T. Marszał (red.), Studia, t. CXX, tom wydany z okazji jubileuszu 50-lecia KPZK PAN, Komitet Przestrzennego Zagospodarowania Kraju Polska Akademia Nauk, Warszawa.

9. Corolleur F., Mangematin V., Torre A., 2003, French Biotech Start Ups and Biotech Clusters in France: The Importance of Geographic Proximity [w:] Biotechnology in Comparative Perspective Growth and Regional Concentration, G. Fuchs and B. Luib, London: Routeledge, s. 221-275.

10. Domański B., 2001, Kapitat zagraniczny w przemyśle Polski. Prawidłowości rozmieszczenia, uwarunkowania i skutki, IGiGP UJ, Kraków.

11. Domański B., 2002, Problemy metod badań inwestycji zagranicznych w układach przestrzennych [w:] Możliwości i ograniczenia zastosowań metod badawczych w geografii społeczno-ekonomicznej i gospodarce przestrzennej, H. Rogacki (red.), Bogucki Wydawnictwo Naukowe, Poznań, s. 197-206.

12. Domański B., 2008, Rozwój polskich metropolii a regiony peryferyjne. Bezpowrotna separacja czy wspótzależność rozwoju?, Studia KPZK PAN, s. 120, 135-143.

13. Domański B., Guzik R., Gwosdz K., 2000, Konkurencyjność i ranga wielkich miast Polski w świetle inwestycji zagranicznych firm produkcyjnych, Biuletyn Komisji Przestrzennego Zagospodarowania Kraju PAN, s. 99-124, 192.

14. Ernest\&Young et Associés, 2010, Baromètre Associés Attractivité du site France 2010, France Valeur mundiale?

15. Goldberg I., Goddard G., Kuriakose S., 2008, Building Knowledge-Based Economy and Absorptive Capacity to Enhance Growth: The Role of Cross-Border Knowledge Flows in Europe and Central Asia (ECA) [w:] Knowledge-Based Economy as Factor of Competitiveness and Economy Growth, M. Runiewicz-Wardyn, L. Koźmiński (ed.), Academy of Entrepreneurship and Management, Warszawa.

16. Gorzelak G., 2003, Bieda i zamożność regionów [w:] Wymiar i współczesne interpretacje regionu, I. Sagan, M. Czepczyński (red.), Uniwersytet Gdański, Katedra Geografii Ekonomicznej, Gdańsk-Poznań, s. 57-77.

17. Institut national de la statistique et des études économiques - Définitions et méthodes, 2010, http:// www.insee.fr/fr/methodes/ 
18. Kudełko J., 1996, Miejsce inwestycji zagranicznych w gospodarce kraju [w:] Wpływ procesów na transformacji gospodarki narodowej na funkcjonowanie jednostek gospodarczych i układów przestrzennych, Z. Zioło (red.), Komisja Geografii PTG, Instytut Geografii Wyższej Szkoły Pedagogicznej w Krakowie, Warszawa, s. 138-145.

19. Lundin N., Sjöholm F., Qian J., 2006, The role of small firms in china's technology development, Working Paper, European Institute of Japanese Studies 227, Stockholm, Szwecja.

20. Majewska M., Grala J., 2002, Wpływ zagranicznych inwestycji bezpośrednich na proces umiędzynarodowienia gospodarki polskiej, „Sprawy Międzynarodowe”, Nr 3, s. 72-91.

21. Mangematin V., Lemarié S., Catherine D., 2001, French ag-biotech smes: development prospects, AgBioForum, Vol. 4, Nr 2, s. 98-104.

22. Markowski T., 2008, Gospodarka bazująca na wiedzy (GOW) a wyzwania wobec zagospodarowania przestrzennego - konceptualizacja problemu [w:] Rola polskich aglomeracji wobec wyzwań strategii lizbońskiej, T. Marszał (red.), Studia, t. CXX, tom wydany z okazji jubileuszu 50-lecia KPZK PAN, Komitet Przestrzennego Zagospodarowania Kraju Polska Akademia Nauk, Warszawa.

23. Myrdal G., 1957, Economic theory and underdeveloped regions, Duckworth, Londyn.

24. Namyślak B., 2002, Bezpośrednie inwestycje zagraniczne a konkurencyjność regionów [w:] Przedsiębiorczość i innowacyjność jako czynniki rozwoju regionalnego i lokalnego, W. Kosiedowski (red.), Uniwersytet M. Kopernika w Toruniu, Włocławskie Towarzystwo Naukowe, Włocławek, s. 353-357.

25. Rachwał T., 2000, Wpływ inwestycji zagranicznych na zmiany w funkcjonowaniu Huty Szkła Jarosław S.A. w procesie transformacji gospodarczej, „Rocznik Naukowo-Dydaktyczny AP w Krakowie”, z. 209, Prace Geograficzne XVIII, Z. Zioło (red.), s. 63-72.

26. Sala S., 2006, Bezpośrednie inwestycje zagraniczne a procesy globalizacji [w:] Międzynarodowe uwarunkowania rozwoju przemystu, Z. Zioło, T. Rachwał (red.), „Prace Komisji Geografii Przemysłu PTG”, nr 8, Komisja Geografii Przemysłu PTG oraz Zakład Przedsiębiorczości i Gospodarki Przestrzennej Instytutu Geografii Akademii Pedagogicznej w Krakowie, Warszawa-Kraków, s. 80-90.

27. Skrzypek E., 2007, Rola wiedzy we wspótczesnym zarządzaniu [w:] Polskie firmy wobec globalizacji, A. Sitko-Lutek (red.), PWN, Warszawa.

28. Smętkowski M., 2001, Nowe relacje między metropolia a regionem w gospodarce informacyjnej, „Studia Regionalne i Lokalne”, nr 4.

29. Sobala-Gwosdz A., 2006, Bezpośrednie inwestycje zagraniczne w województwie podkarpackim do końca 2003 r. [w:] Efekty restrukturyzacji polskiej przestrzeni przemystowej, Z. Zioło i T. Rachwał (red.), „Prace Komisji Geografii Przemysłu PTG”, nr 9, Komisja Geografii Przemysłu PTG oraz Zakład Przedsiębiorczości i Gospodarki Przestrzennej Instytutu Geografii Akademii Pedagogicznej w Krakowie, Warszawa-Kraków, s. 181-191.

30. Stryjakiewicz T., 2004, Wpływ inwestycji zagranicznych na rozwój regionalny i lokalny na przykładzie GlaxoSmithKline Pharmaceuticals S.A. w Poznaniu, Bogucki Wydawnicwto Naukowe, Poznań.

31. Stryjakiewicz T., 2008, Sektor kreatywny jako czynnik kształtujacy nowa jakość przestrzeni europejskiej [w:] Przekształcanie regionalnych funkcjonalno-przestrzennych. Europa bez granic - nowe wyzwania, D. Ilnicki, K. Janc (red.), Rozprawy Naukowe Instytutu Geografii i Rozwoju Regionalnego Uniwersytetu Wrocławskiego 3, Instytut Geografii i Rozwoju regionalnego Uniwersytetu Wrocławskiego, Wrocław, s. 11-18.

32. Stryjakiewicz T., 2009, Lokalizacja firm i zachowania przestrzenne pracowników sektora informatycznego (na przykładzie poznańskiego obszaru metropolitalnego) [w:] Funkcje przemystu w ksztattowaniu społeczeństwa informacyjnego, Z. Zioło i T. Rachwał (red.), „Prace Komisji Geografii Przemysłu PTG", nr 13, Komisja Geografii Przemysłu PTG oraz Instytut Geografii Uniwersytetu Pedagogicznego w Krakowie, Warszawa-Kraków, s. 21-33.

33. World Investment Report 1998, Trends and Determinants, United Nations, New York and Geneva. 


\section{Foreign Investments in France in the Period of Globalization}

The turn of the 20th and 21st centuries brought an intensive increase of international economic connections that were a part of the process of globalization of the world economy. The result of these processes was opening of the countries' economies which influenced the increase of the role of foreign investments as a factor of economic development of a country.

Foreign direct investments (FDI) are nowadays one of the most sought-after forms of foreign capital flow. Foreign investments do not cause external debt. They influence the flow of technology, generate economic growth, contribute to the decrease in unemployment, introduce new management methods, create access to the new markets and generate production infrastructure. The following study presents a short characteristic of foreign investments in France. It analyses regional differentiation of foreign investments in France on the basis of their quantity and in reference to the number of workplaces generated by FDI. Finally, the article presents the factors that have influence on the localization of foreign investments. 